\title{
THE ATHENIAN REPUBLIC
}


Also by Raphael Sealey

\begin{abstract}
A History of the Greek City States ca. 700-338 B.c. Essays in Greek Politics
\end{abstract}




\section{THE \\ ATHENIAN \\ REPUBLIC}

Democracy or the Rule of Law?

\section{RAPHAEL SEALEY}

The Pennsylvania State University Press

University Park and London 
Library of Congress Cataloging-in-Publication Data

Sealey, Raphael.

The Athenian Republic.

Bibliography: $p$.

Includes index.

1. Rule of law-Greece-Athens. 2. Courts-GreeceAthens. 3. Athens (Greece)-Constitutional law.

I. Title.

LAW $340.5^{\prime} 3^{\prime} 85 \quad 86-9512$

ISBN 0-271-00443-6

Copyright () 1987 The Pennsylvania State University All rights reserved 


\section{To \\ Dorte-Freyja Sealey}


This page intentionally left blank. 